\title{
МЕТАФОРА В БІОЛОГІЧНІЙ ТЕРМННОСИСТЕМІ (українсько-польські паралелі)
}

\author{
МАРІЯ КУХАРЧИШИН \\ Львівський національний університет імені Івана Франка, Львів - Україна \\ mariafilolog@ukr.net; ORCID: 0000-0003-2314-9601
METAFORA W BIOLOGICZNYM SYSTEMIE TERMINOLOGICZNYM
(paralele języka ukraińskiego i polskiego) \\ MARIA KUCHARCZYSZYN \\ Lwowski Uniwersytet Narodowy imienia Iwana Franki, Lwów — Ukraina
}

STRESZCZENIE. Artykuł poświęcony jest analizie metafory jako środka tworzenia terminów w terminologii biologicznej. Określona została rola metafory w naukowym obrazie świata w języku ukraińskim i polskim. Opisano skojarzenia, które stały się podstawą przeniesienia metaforycznego.

Słowa kluczowe: metafora, termin, terminologia biologiczna, język ukraiński, język polski, skojarzenie, przeniesienie metaforyczne.

\author{
METAPHOR IN BIOLOGICAL TERMINOLOGY \\ (Ukrainian-Polish parallels) \\ MARIA KUKHARCHYSHYN \\ Ivan Franko Lviv National University, Lviv - Ukraine
}

ABSTRACT. The article focuses on the analysis of metaphor as a way of creating terms in a biological terminology. The role of the metaphor in creation the scientific picture of the world of the Ukrainian and Polish languages has been described. It has been found out which associations became the basis of a metaphorical transfer.

Key words: metaphor, term, biological terminology, the Ukrainian language, the Polish language, association, metaphorical transfer.

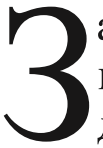
а останні десятиліття проведено низку досліджень, присвячених проблемі метафоричного перенесення, що свідчать про глибоку зацікавленість нею дослідників. Сьогодні пояснення механізму метафори - це питання численних теорій. В українському мовознавстві метафору як засіб термінотворення досліджують О. Винник, І. Кочан, О. Кримець, Л. Малевич, Г. Мацюк, О. Селіванова, Л. Симоненко, Н. Цісар та ін. У польській лінгвістичній науці метафору в науковій мові на прикладі природничих наук розглядає Magdalena Zawisławska ${ }^{1}$, a Stanisław Gajda пише про метафору в науковому дискурсі².

Науковці (напр., Л. Васенко, О. Кримець) згрупували концепції інтерпретації метафори в чотири типи, зокрема це: 1) теорія семантичного зрушення, що $є$ першою спробою аналізу того, як створюються метафори; 2) інтеракційна теорія, що поглибила й розширила пошук відповіді на це питання; 3) когнітивна теорія 2011.

${ }^{1}$ M. Zawisławska, Metafora w języku nauki: na przykładzie nauk przyrodniczych, Warszawa

2 S. Gajda, Metafora $w$ dyskursie naukowym, [w:] „Studia Litteraria Polono-Slavica”, vol. 8, red. E. Hałoń, Warszawa 2008, s. 29-42. 
метафори, що дає можливість комплексного розв'язання проблеми творення метафори, включаючи в цей процес саму людину; 4) концептуальна теорія метафори, що визначає метафору як процес розуміння одного концепту в термінах іншого ${ }^{3}$. Найпопулярнішою з них є концептуальна. У іiі рамках метафору тлумачать як вербалізований спосіб сприйняття й усвідомлення світу, універсальний пізнавальний механізм. Ідеться про метафору не як власне мовне явище, а як явище концептуальне. Теорія концептуальної метафори, основоположниками якої є G. Lakoff, M. Johnson у широковідомій праці ${ }^{4}$, сприяла загальній зміні концепції сучасної термінотворчості: у наукових дослідженнях усе частіше постулюють думку, що без метафоризації неможливо було б створити будь-яку наукову мову, зокрема іiі терміносистему. „Метафора служить з огляду на сучасну лінгвосинергетичну наукову парадигму потужним атрактором, тобто параметром самоорганізації, чинником збереження й розвитку термінологічної системи в мові, забезпечує креативні механізми будь-якої фахової сфери знань, адже необмеженість пізнавальних можливостей людини зумовлює потребу в нових і нових мовних позначеннях", - зазначає О. Селіванова. Л. Алексєєва в праці Термін і метафора впроваджує категорії термінологічної метафоризації і вважає, що метафори не суперечать дослідницькому розуму, оскільки вони закладені в мисленнєвій діяльності, метафоричні терміни надають еволюційний характер усій терміносистемі, оскільки саме через них передається динаміка й новітність знання ${ }^{6}$. Крім того, дослідниця розширює межі розуміння термінологічної метафори, уважаючи, що не метафори є різновидом процесу термінотворення, а термінотворення входить у метафоризацію як іiї складник.

Механізм метафоризації грунтується на взаємодії донорської зони (source domain) і реципієнтної зони (target domain). „Перенесення знака з однієї зони в іншу відбувається внаслідок формування у свідомості мовця їхнього можливого суміщення на підставі етнічних стереотипів, міфологем, архетипів колективного позасвідомого" . Донорська зона є постачальником мовних знаків для реципієнтної зони і зазвичай доступніша носіям для іï розуміння. Відтак метафора в терміносистемах сприяє декодуванню нового терміна на основі знань про узвичаєне, зрозуміліше. Це дає підстави вважати, що метафора і вмотивовує термін, і може слугувати своєрідним маркером нефахівцям для тлумачення його значення. "Якщо художня метафора - це загадка (говорить одне, а спонукає до усвідомлення зовсім іншого), то наукова метафора — це розгадка (говорить одне, а спонукає до усвідомлення подібного)"».

За спостереженнями В. Вовк, „будівля науки споруджується на гіпотезі, і саме метафора зі своєю гіпотетичною природою здатна найточніше відбивати цю рису. Метафора дозволяє миттєво усвідомити, схопити саму суть відкритого явища або поняття, проникнути в його зміст". Саме тому вивчення метафори

3 Л. А. Васенко, О. М. Кримець, Термінологічна метафоризаиія як репрезентація нового наукового знання, [в:] „Вісник Нац. ун-ту «Львівська політехніка». Серія «Проблеми української термінології»”, Львів 2006, № 559, с. 59.

${ }^{4}$ G. Lak off, M. Johnson, Metaphors We Live By, Chicago 1980.

${ }^{5}$ О. О. Селіванова, Когнітивне підтрунтя метафоризаиії російської лінгвістичної термінологіï, [в:] „Ученые записки Таврического национального университета им. В. И. Вернадского”. Серия «Филология. Социальные коммуникации»”, Симферополь 2011, том 26 (65), № 1, с. 287.

${ }^{6}$ Л. М. Алексеева, Термин и метафора, Пермь 1998, с. 20-22.

${ }^{7}$ Е. А. Селиванова, Энигматический дискурс: вербализачия и когниция, Черкассы 2014, с. 97.

8 Л. М. Алексеева, указ. источ., с. 128.

${ }^{9}$ В. Н. Вовк, Языковая метафора в художественной речи: Природа вторичной номинации, Киев 1986, с. 98. 
дає змогу побачити, з чого починає свій розвиток значення слова. Характер наукового мислення, у якому велику роль відіграє асоціативне, сприяє метафоричному перенесенню. Метафоричне перенесення назви зумовлене певними асоціативними зв'язками між різними референтами на основі схожості загальних характеристик і асоціацій, пов'язаних із референтом; зовнішньої схожості предметів; функціональної схожості.

Як засвідчує опрацьований матеріал, підставою для метафоричного перенесення в біологічній терміносистемі можуть служити асоціації за зовнішньою подібністю, схожістю функцій, одночасною зовнішньою і функціональною подібністю.

- Зовнішня схожість лежить в основі створення таких біологічних термінів: батіг, бляшки, віночок, вузол, дуга, лабіринт, книжка, китичя, кошик, парус, пластинка, раковина, рубець, сітка, паличка, пляма, розетка, човник тощо. Порівняймо: у загальновживаній мові слово книжка позначає 'зброшуровану в одне ціле й оправлену певну кількість (зазвичай понад 5) друкованих або рукописних аркушів' ${ }^{10}$. У біологічній термінології книжкою називають 'передостанній відділ багатокамерного шлунку більшості жуйних тварин на всій внутрішній поверхні, крім дна, слизова оболонка якого утворює різної висоти поздовжні складки - листочки, що нагадують аркуші книжки' ${ }^{11}$; кошик у загальному вжитку - це 'виріб, різний за формою та розміром, виплетений з лози, стебел рогозу, дранки тощо, який використовують у побуті для зберігання або перенесення чого-небудь' ${ }^{12}$; у біології кошик - це 'просте ботричне суцвіття рослин родини складноцвітних, яке складається із щільно прилеглих одна до одної квіток на розширеному кінці вкороченої осі плоскої, опуклої або ввігнутої форми'13.

- схожість за функцією стала основою для створення термінів: мантія, мішень, покривало, обгортка, обкладка, оператор, хазяїн, чохлик.

За схожістю функцій із чохликом, що в загальновживаній мові називає 'покриття або футляр 3 матерії чи іншого матеріалу, зроблений за формою якогось предмета для захисту його від пошкодження, забруднення і т. ін. ${ }^{14}$; у біології позначають 'вмістилище личинок або групу великих клітин з потовщеними оболонками на кінці кореня рослин, що виконує захисну функцію від механічного впливу при його рості (кореневий чохлик) ${ }^{\prime 15}$. Інтегральною семою виступає 'захист'. У загальномовному лексиконі мімень - 'штучна або природна ціль при навчальній та тренувальній стрільбі' ${ }^{16}$, у біологічному словнику мiшень - “1. молекулярна структура в біологічному об'єкті, при влученні в яку іонізивне випромінювання зумовлює біологічний ефект, наслідком якого є генна мутація або розрив хромосоми, макрозміни організму в цілому; 2. тканина, проти якої утворюються антитіла, або тканина, що специфічно реагує на певний гормон” ${ }^{\prime 17}$. Інтегральною семою є 'ціль'.

- До термінів, створених на основі одночасної зовнішньої й функціональної подібності, належать: мімок, парамут, трубка, канал.

\footnotetext{
${ }^{10}$ Словник української мови, в 11 томах, гол. ред. І. К. Білодід, Київ 1970-1980, т. 4, с. 197.

${ }^{11}$ Словник української біологічної термінологї, Київ 2012, с. 280.

${ }^{12}$ Словник украйнської мови, в 11 томах..., т. 4, с. 316.

${ }^{13}$ Словник украӥнської біологічної термінологї..., с. 251.

${ }^{14}$ Словник української мови, в 11 томах..., т. 11, с. 370.

${ }^{15}$ Словник української біологічної термінологї..., с. 601.

${ }^{16}$ Словник української мови, в 11 томах..., т. 4, с. 761.

${ }^{17}$ Словник украйнської біологічної термінологї..., с. 298.
} 
За одночасною схожістю функціональною і зовнішньою в біологію мігрувало загальновживане слово трубка — 'довгий порожнистий предмет або пристрій, звичайно кільцевого перерізу, призначений для переміщення рідини, пари, газу ін. ${ }^{18}$. Термін трубка позначає 'видовжену порожнисту структуру, стебло злаків під час росту' ${ }^{\prime}$. Інтегральні семи 'видовжена форма' та 'функція перенесення або сполучення'. Парашут — 'пристрій у вигляді великої парасольки, що розкривається в повітрі для стрибка людини з літального апарата, для спуску з нього вантажу або взагалі для гальмування' 20 і napawym - біологічний термін, що називає 'парасолькоподібне утворення ззовні плодів, яке має пучок волосків і слугує для перенесення плодів вітром'21. Метафоричному перенесенню сприяли асоціації за зовнішньою подібністю до парасольки й однаковою функцією — переміщення.

Терміни, що виникли на основі метафори, є показовими в національномовній картині світу. Метафора - наскрізний приклад синтетичної природи мови та мислення. Термінологія має найтісніший зв'язок із категоріями мислення, бо формування термінів зумовлюється мовною свідомістю людей, які їх створюють. Л. Малевич висловлює думку про те, що „терміни-метафори виступають ключовими елементами для розуміння національної специфіки мовного бачення навколишнього світу, вони пов'язані з культурою народу й відбивають результати когнітивної (пізнавальної) діяльності національного мовного колективу"22. Термінологія певної мови віддзеркалює наукову картину світу. Дослідники стверджують, що наукова картина світу й картина світу національної мови тісно пов'язані, більше того, наукова картина світу в мовній оболонці будь-якої національної мови дає привід для роздумів про національний образ мислення, відбиває менталітет нації ${ }^{23}$.

Цікаво із цих позицій розглянути, як вербалізується зміст наукового знання засобами національної мови для виявлення спільних та відмінних особливостей термінотворення на прикладі біологічної термінології української та польської мов. Біологія як наука вивчає життя в усіх його проявах, вона має давню історію й нині активно розвивається (нові галузі, відкриття). Безперервний зв'язок людини з природою, іiі залежність від природи збагатили людину знаннями про тваринний, рослинний, пташиний світ, власне тіло. Ці знання змінювалися та доповнювалися за різних умов. Тому в біологічній термінології певної мови зафіксована пізнавальна діяльність людини, підсумки наукового пізнання світу, світооцінка. Основою біологічних термінів окремої мови стає ментально-культурна специфіка та мовна картина світу їі носіїв. Зіставний аналіз надає можливість глибшого розкриття особливостей відображення світу в термінології рідної мови та в національній культурі поряд з іншими мовними картинами світу, сприяє виявленню як загальнослов' янських тенденцій, так і специфічних національних особливостей розбудови сучасних терміносистем.

${ }^{18}$ Словник украӥнської мови, в 11 томах..., т. 10, с. 290.

${ }^{19}$ Словник української біологічної термінології..., с. 557.

${ }^{20}$ Словник украӥнської мови, в 11 томах..., т. 6, с. 67.

${ }^{21}$ Словник української біологічної термінології..., с. 380.

22 Л. Д. Малев ич, Метафора в науковій картині світу, [в:] „Українська термінологія і сучасність", зб. наук. праць, Київ 2003, вип. V, с. 224.

${ }^{23}$ О. М. Кримець, Термінологізачія та детермінологізаиія як результат взаємовпливу мовної та наукової картин світу, [в:] „Вісник Нац. ун-ту «Львівська політехніка». Серія «Проблеми української термінології»”, Львів 2015, № 817, с. 36. 
I. Кочан зазначає, що розвиток української термінології має специфічний характер порівняно з термінологією інших європейських мов. Формування іiі відбувалося під впливом російської та польської мов. Мала вплив також мова німецьк $\mathrm{a}^{24}$. Це спричинено, очевидно, територіальним сусідством, історичними, економічними, культурними чинниками. У біологічній термінології, крім цих факторів, визначальним $є$ те, що в обох мовах значним пластом $є$ лексеми, які утворилися на основі латинської мови, але в польській мові кількість таких термінів є помітно меншою, бо, як відомо, там усталилася традиція термінологічної націоналізації. Відомий польський учений Jan Śniadecki стосовно цього писав, що „затемнює і спотворює мову чужоземщина: це напрямок і спосіб висловлення думки, взятий з чужих мов, а нашій не властивий. Як на мене, помиляються ті, хто гадає, що мова збагачується, коли до своїх шат приймає чужоземне. Насправді це найкоротший і битий шлях до ії згуби"25.

Існує ряд біологічних термінів української мови, що за значенням, структурою, функційними особливостями ідентичні з польськими: кістка - kość, кров - krew, запилення - zapylenie, корінь - korzen, нерв - nerw, жовч-żótć, гормон - hormon, лопатка - topatka, променева кістка - kość promieniowa, кора мозку — kora тózgu, клен звичайний — klon zwyczajny. Назва українського терміна личинка, що позначає одну з перших стадій розвитку живого організму (черв'яків, комах), виникла на основі слова личина (маска), у польській мові larwa теж мотивується словом maska. Причиною цього $є$ те, що на цій стадії розвитку личинка відрізняється анатомічно й фізіологічно від зрілої особини, тобто “маскується”. В обох мовах існує також переносне значення: 'людина, що приховує свою істинну сутність'. Це зумовлено близькістю мовних картин світу, зближенням частини біологічних термінів унаслідок спільного походження.

Оскільки творцем терміна є людина зі своєю культурою, ментальністю, то наукові поняття, вербалізуючись засобами тієї чи тієї національної мови, наповнюються новим змістом, властивим лігвокультурній спільноті, представником якої $\epsilon$ термінотворець. Тому окремі біологічні терміни двох мов тотожні за значенням, але різняться звучанням, що зумовлено відмінностями в системі образних асоціативно-оцінних засобів. Напр., назва очеретянка має відповідник у польській мові trzciniak. В обох мовах найменування мотивовані назвою рослини очерет, порівн. польське trzcina — 'очерет'. Об'єктивно найулюбленішими місцями перебування та гніздування цих представників фауни є очеретяні зарості по болотах. Цей факт став найвиразнішою ознакою птаха у світобаченні обох етносів. Отже, у різних мовах назви того самого поняття творилися за допомогою, відповідно, українських та польських мовних ресурсів, але образне сприйняття об'єкта, його асоціативно-метафорична інтерпретація були тотожними.

Різні пізнавальні механізми свідомості були залучені під час формування орнітонімів лунь / błotniak - 'хижий птах родини яструбиних із сірувато-білим пір'ям у самців'. В українській назві акцентуються такі ознаки птаха, як хижий (лупити, обдирати), крім того, актуалізується ознака, пов'язана із забарвленням, - світле, блискуче (луна). Польська ж назва blotniak мотивована словом bloto - болото, що, зрозуміло, пов'язане із середовищем проживання птаха - заболочена місцевість. Бачимо, що в основу номінації покладені різні ознаки.

${ }^{24}$ I. М. Кочан, Термінологія: національна чи міжнародна?, [в:] „Вісник Нац. ун-ту «Львівська політехніка». Серія. «Проблеми української термінології»”, Львів 2009, № 648, с. 4.

${ }_{25}$ Цит. за: П. О. Селігей, Пуризм у термінології: український досвід на європейському $m л і$, [в:] „Мовознавство”, Київ 2008, № 1, с. 56. 
В українському номені ломиніс закодована інформація про стан людини після ії контакту з рослиною. Оскільки ця рослина містить у своєму складі отруйну речовину, що має специфічний запах, під час контакту зі шкірою вона викликає появу набряків. У польському фітонімі powojnik мотиваційною ознакою стає здатність рослини витися. Польський номен bocian походить від botat' - 'тупати, дибати', що обумовлено зовнішніми ознаками птаха. Українська назва лелека мотивується звуконаслідуванням läiläk. Ці приклади підтверджують, що донорські зони для метафоричних назв номінатори обирають з урахуванням принципів метафоризації, притаманних мові й етносвідомості.

Орнітонім рибалочка виник завдяки виділенню стійкої асоціації в уявленні українців про те, що птах живиться рибою. Польська ж назва zimorodek (від zima - зима) зумовлена знаннями носіїв мови про те, що ці розповсюджені в Європі птахи на зимівлю не відлітають до теплих країв, а перебираються в південні області поширення виду.

Український фітонім жовтещь отримав назву від жовтого забарвлення пелюстків квітки, у польському терміні jaskier (від iskra) підкреслюється інформація про властивості рослини, зокрема про ії отруйність. Контакт з квіткою викликає почервоніння шкіри, запалення, шкіра пече, наче “іскриться". Тому вважаємо цілком слушною думку Н. Родзевич про те, що „метафоричний засіб творення термінів в жодній галузі наук не використаний так активно, як в ботаніці, причому він своєрідний, часто не пов'язаний 3 копіюванням метафори із споріднених мов" 26.

Термін печінка в українській мові утворений від дієслова пекти, а польський відповідник wątroba - те, що знаходиться в середині, “в утробі”. Наведені приклади свідчать про різне смислове інтонування терміна в порівнюваних мовах. У термінологічних номінаціях різних мовних культур закарбовуються актуальні для “свідомості соціуму” ознаки предмета найменування. Ці ознаки створюють певні образи, на основі яких виникає метафора. Вона базується на досвіді людини, є тим ключем, що відкриває таємниці взаємодії мовних і ментальних структур.

Метафора стає своєрідним віконцем, яке дає змогу побачити когнітивні та духовні особливості національних мовних картин світу. Напр., український термін ключиия побудований на основі схожості кістки 3 ключем, польський obojczyk (від kołnierz) — 'кістка, що знаходиться біля коміра'. Орнітонім косар — 'птах родини ібісових', мотивується способом здобування їжі. Птахи, які мають цю назву, своєрідно добувають собі їжу: збираються на мілководді і, зануривши дзьоби у воду, рухають головою в різні боки — це нагадує рухи косаря, який водить держаком коси з боку в бік, викошуючи траву. Польська ж назва warzęcha (від warzycha) виникла через порівняння характерного лопатоподібного дзьоба птаха 3 великою дерев'яною ложкою. Терміни-метафори важливий чинник розуміння національної специфіки мовного бачення довкілля. Вони пов'язані з культурою народу й відображають наслідки його пізнавальної діяльності.

Біологічні терміни української та польської мов можуть відрізнятися кількістю значень, обсягом та структурою значення, наявністю / відсутністю або рівнем виявлення оцінно-експресивного компонента. Часто спостерігає-

${ }^{26}$ Н. С. Родзевич, Метафора - спільне джерело творення термінологічної лексики в слов'янських $i$ західноєвропейських мовах, [в:] „Дослідження з лексикографії та лексикології”, республік. міжвідом. зб., Київ 1965, вип. 1, с. 150. 
мо явище, коли семантична й структурна модель утворення терміна в різних мовах не збігаються. Ідеться про зв'язок значення словосполучення-терміна 3 його структурою. Напр., укр. підшлункова залоза — 'залоза, яка знаходиться під шлунком', пол. trzustka (trzos — 'чистота' і tka — 'те, що продукує, творить') — 'орган, що “підтримує чистоту” організму'. У семантиці українського терміна акцентується локативна ознака, а в польському - функційна. Відрізняються вони також структурними моделями: щитовидна залоза - tarczyca, слинна залоза - ślinianki, передміхурова залоза - stercz. Термінологічне поняття входить до складу термінології у вигляді певної синтаксичної моделі терміна-слова чи терміносполучення, що залежить від внутрішньої форми терміна.

Використання терміносполуки надп'яткова кістка для номінації однієї 3 кісток передплесна зумовлене вказівкою на їі індивідуальні особливості (розміщення кістки) та визначення місця в ряду інших однорідних. У польській мові це поняття позначено терміном stęp (від stapać, 'kroczyć - 'ступати, крокувати, йти'), що, імовірно, пов'язано з функцією, тобто підкреслюються атрибутивна та функційна ознаки. Проте структурні й семантичні моделі ряду інших термінів збігаються: променева кістка — kość promieniowa, скронева кістка — kość skroniowa, miм'яна кістка - kość ciemieniowa.

Використання термінів-словосполучень не є випадковим, адже в різних терміносистемах української мови переважають саме такі структури. Аналогічно і в польській мові „основним типом творення термінологічної лексики є тип лексичного словосполучення, морфологічний же тип відходить на задній план"27. У біологічній терміносистемі виникнення словосполучень неминуче, бо їх широко використовують „при систематиці рослинного та тваринного світу, де, як відомо, діє біномінальний принцип, за яким до родової назви додається видова характеристика"28.

Отже, метафора - це завжди актуальне джерело термінотворення в біологічній термінології. Зіставлення біологічної термінології української і польської мов показує, що ідентичні терміноелементи у вказаних мовах виникають на основі спорідненості й близькості двох слов'янських мов, а також як наслідок спільного походження.

Проте виявлені семантичні та структурні розбіжності в термінології, що пов'язані головно зі специфікою національно мовного світобачення, своєрідною мовною картиною. Позаяк у семантиці термінів закладений культурноісторичний і загальнолюдський досвід, а конкретна мова пропонує засоби для їхньої вербалізації.

Терміни - це джерело інформації, що репрезентує специфіку мовного бачення навколишнього світу. Творення термінів відбувається в порівнюваних мовах за певними номінативно-мотивувальними ознаками. Ці ознаки - "нитки” значення, що створюють клубочок, який відображає наукове поняття. Важливу роль у цьому процесі відіграє метафора, що створює образно-асоціативне тло.

Отже, метафоризовані терміни мають особливі значення та структуру, відображають оригінальні національні психолінгвістичні механізми і сприяють розумінню мови та людини в ній.

27 Л. Л. Гумецька, Нарис словотворчої системи української актової мови IV-XV cm., Київ 1958.

28 Л. О. Симоненко, Формування украӥнської біологічної термінологї̈, Київ 1991, с. 24. 


\section{Список використаної літератури}

Алексеева Л. М., Термин и метафора, Пермь 1998.

Васенко Л. А., Кримець О. М., Термінологічна метафоризачія як репрезентація нового наукового знання, [в:] „Вісник Нац. ун-ту «Львівська політехніка». Серія «Проблеми української термінології»”, Львів 2006, № 559, с. 57-60.

Вовк В. Н., Языковая метафора в художественной речи: Природа вторичной номинации, Київ 1986.

Гумецька Л. Л., Нарис словотворчої системи украӥнської актової мови IV-XV cm., Київ 1958.

Кочан I. М., Термінологія: начіональна чи міжнародна?, [в:] „Вісник Нац. ун-ту «Львівська політехніка». Серія «Проблеми української термінології»”, Львів 2009, № 648, c. 3-8.

Кримець О. М., Термінологізачія та детермінологізація як результат взаємовпливу мовної та наукової картин світу, [в:] „Вісник Нац. ун-ту «Львівська політехніка». Серія «Проблеми української термінології»”, Львів 2015, № 817, с. 36-40.

Малевич Л. Д., Метафора в науковій картині світу, [в:] „Українська термінологія і сучасність”, зб. наук. праць, Київ 2003, вип. V, с. 224-227.

Родзевич Н. С., Метафора - спільне джерело творення термінологічної лексики в слов'янських $i$ західноєвропейських мовах, [в:] „Дослідження з лексикографії та лексикології, республік. міжвідом. зб., Київ 1965, вип. 1, с. 137-165.

Селіванова О. О., Когнітивне підгрунтя метафоризачії російської лінгвістичної термінологіï, [в:] „Ученые записки Таврич. нац. ун-та им. В. И. Вернадского. Серия «Филология. Социальные коммуникации»”, Симферополь 2011, т. 26 (65), № 1, c. $286-292$.

Селиванова Е. А., Энигматический дискурс: вербализация и когниция, Черкассы 2014.

Селігей П. О., Пуризм у термінології: украӥнський досвід на європейському тлі, [в:] „Мовознавство”, Київ 2008, № 1, с. 49-66.

Симоненко Л. О., Формування української біологічної термінологї, Київ 1991.

Словник української біологічної термінологї, Київ 2012.

Словник української мови, в 11 томах, гол. ред. І. К. Білодід, Київ 1970-1980, т. 4.

Gajda S., Metafora $w$ dyskursie naukowym, [w:] „Studia Litteraria Polono-Slavica”, vol. 8, red. E. Hałoń, Warszawa 2008, s. 29-42.

Lakoff G., Johnson M., Metaphors We Live By, Chicago 1980.

Zawisławska M., Metafora w języku nauki: na przykładzie nauk przyrodniczych, Warszawa 2011.

\section{Spysok vykorystanoi literatury [References]}

Alekseeva L. M., Termin i metafora [Term and Metaphor], Perm 1998.

Vasenko L. A., Krymets O. M., Terminolohichna metaforyzatsiia yak reprezentatsiia novoho naukovoho znannia [Terminological Metaphorization as Representation of New Scientific Knowledge], [v:] „Visnyk Nats. un-tu «Lvivska politekhnika». Seriia «Problemy ukrainskoi terminolohii»”, Lviv 2006, № 559, s. 57-60.

Vovk V. N., Jazykovaja metafora $v$ hudozhestvennoj rechi: Priroda vtorichnoj nominacii [Language Metaphor in Fiction Speech: Origin of Secondary Nomination], Kyiv 1986.

Humetska L. L., Narys slovotvorchoi systemy ukrainskoi aktovoi movy IV-XV st. [Sketches on Word-Formation System of the Ukrainian Language of the IV-XVth centuries], Kyiv 1958.

Kochan I. M., Terminolohiia: natsionalna chy mizhnarodna? [Terminology: National or International?], [v:] „Visnyk Nats. un-tu «Lvivska politekhnika». Seriia «Problemy ukrainskoi terminolohii»”, Lviv 2009, № 648, s. 3-8. 
Krymets O. M., Terminolohizatsiia ta determinolohizatsiia yak rezultat vzaiemovplyvu movnoi ta naukovoi kartyn svitu [Terminologization and Determinologization as Result of Mutual Influence of Liguistic and Scientific World Images], [v:] „Visnyk Nats. un-tu «Lvivska politekhnika». Seriia «Problemy ukrainskoi terminolohii»", Lviv 2015, № 817, s. $36-40$.

Malevych L. D., Metafora v naukovii kartyni svitu [Metaphor in Scientific World Image], [v:] „Ukrainska terminolohiia i suchasnist”, zb. nauk. prats, Kyiv 2003, vyp. 5, s. 224-227.

Rodzevych N. S., Metafora — spilne dzherelo tvorennia terminolohichnoi leksyky v slovianskykh i zakhidnoievropeiskykh movakh [Metaphor - Common Sourse of Terminological Lexis Formation in Slavic and Western European Languages], [v:] „Doslidzhennia z leksykohrafii ta leksykolohii", respublik. mizhvidom. zb., Kyiv 1965, vyp. 1, s. 137-165.

Selivanova O. O., Kohnityvne pidgruntia metaforyzatsii rosiiskoi linhvistychnoi terminolohii [Cognitive Grounds of Metaphorisation of Russian Linguistic Terminology], [v:] „Uchenie zapysky Tavrych. nats. un-ta ym. V. Y. Vernadskoho. Seryia «Fylolohyia. Sotsyalnie kommunykatsii»", Symferopol 2011, t. 26 (65), № 1, s. 286-292.

Selivanova E. A., E`nigmaticheskij diskurs: verbalizaciya i kogniciya [Enigmatic Dicourse: Verbalization and Cognition], Cherkassy 2014.

Selihei P. O., Puryzm u terminolohii: ukrainskyi dosvid na yevropeiskomu tli [Purism in Terminology: Ukrainian Experience on European Background], [v:] „Movoznavstvo”, Kyiv 2008, № 1, s. 49-66.

Symonenko L. O., Formuvannia ukrainskoi biolohichnoi terminolohii [Ukrainian Biological Terminology Formation], Kyiv 1991.

Slovnyk ukrainskoi biolohichnoi terminolohii [Dictionary of Modern Ukrainian Biological Terminology], Kyiv 2012.

Slovnyk ukrainskoi movy [The Ukrainian Language Dictionary], v 11 tomakh, hol. red. I. K. Bilodid, Kyiv 1970-1980, t. 4.

Gajda S., Metafora w dyskursie naukowym [Metaphor in Scientific Discourse], [w:] „Studia Litteraria Polono-Slavica", vol. 8, red. E. Hałoń, Warszawa 2008, s. 29-42.

Lakoff G., Johnson M., Metaphors We Live By, Chicago 1980.

Zawisławska M., Metafora w języku nauki: na przykładzie nauk przyrodniczych, Warszawa 2011. 